\title{
Factors Related to the Provision of DPT Immunization in Baduta in the Meureubo Puskesmas Working a West Aceh Regency 2018
}

Susy Sriwahyuni ${ }^{1, *}$, Zakiyuddin ${ }^{1}$, Muhammad Reza Firdaus ${ }^{1}$, Darmawan $^{1}$, Tuty

Alawiyah $^{1}$

\author{
${ }^{1}$ Faculty of Public Health, Universitas Teuku Umar, Jl. Alue Peunyareng, 23615, Aceh Barat, Indonesia \\ *Corresponding author. Email: susysriwahyuni@utu.ac.id
}

\begin{abstract}
Immunization is a prevention effort that has succeeded in reducing infectious morbidity and mortality in infants and children. Based on a preliminary study on mothers who have baduta, there is still a low knowledge of mothers where mothers who do not want to give immunizations to the clan, then the mother does not pay attention to the benefits that will be obtained by the mother of immunization. The purpose of the study was to find out the factors related to DPT immunization at Baduta. The research method uses analytical survey design with a cross sectional survey approach. The population is all mothers who have the target of DPT immunization as many as 845 million and a sample of 89 people, the sampling technique is using simple random sampling technique and analyzed by univariate and bivariate using the chisquare test. The results of the study showed a significant relationship between knowledge factors $(\operatorname{Pvalue}=0,000<\alpha=$ 0.05 ), attitudes (Pvalue $=0.035<\alpha=0.05$ ), actions (Pvalue $=0.035<\alpha=0.05$ ), health services (Pvalue $=0.020$ $<\alpha=0.05$ ), family support (Pvalue $=0.020<\alpha=0.05$ ), with DPT immunization. It was concluded that there was a significant relationship between the factors of knowledge, attitudes, actions, health services, family support, and DPT immunization. It is recommended for Meureubo Health Center to carry out health promotion policies to further develop promotive and preventive programs.
\end{abstract}

Keywords: Knowledge, attitudes, actions, DPT

\section{INTRODUCTION}

Health development is essentially the implementation of health efforts for each population in order to realize optimal public health. One effort to achieve this state is to reduce morbidity and mortality rates for infants and toddlers [1]. Immunization as an effort to prevent various types of diseases is a necessity that cannot be delayed.

This is related to the increase in human resources in the future. Our main task as health workers is to provide parents with knowledge about immunization and review the immunization status of each child Giving immunization to infants and children not only provides prevention of certain diseases to these children, but also has a wider impact because it can prevent transmission of disease to other children. Therefore the knowledge and attitude of parents, especially mothers, is very important to understand the benefits of immunization for Indonesian children [2]

Provision of immunization prematurely is not justified because the baby still gets immunity from the mother. If the next immunization is less than the specified distance, it will cause the vaccine reaction to be less than optimal because the vaccine concentration in the body is still high, so also if the next immunization retreats the vaccine concentration is still below the threshold and even allows germs to enter, so that when the next immunization is given the reaction not optimal. Immunization was first discovered for smallpox. This disease has killed millions of people in Europe and around the world, whereas in the United States a hundred years ago there were still 48,000 smallpox mattresses recorded annually. The polio virus was first discovered by Landsteiner and Popper in 1909.

Immunization is one way to overcome the Tetanus virus. Diphtheria is a disease caused by the bacterium Corynebacterium diphtheria. Diphtheria is malignant, easily transmitted and attacks especially the upper respiratory tract. Transmission can be due to direct contact with patients through sneezing or coughing or indirect contact because of food contaminated with diphtheria bacteria. Patients will experience some symptoms such as fever of approximately $38^{\circ} \mathrm{C}$, nausea, vomiting, pain when swallowing and there is a grayish white pseudomembrane in the pharynx, larynx, or tonsils.

Tetanus can be prevented through immunization by giving DPT vaccines to children [3]. Pertussis is a disease caused by Bordetella Pertussis bacteria. These germs release toxins that cause a threshold of excitatory cough that is severe and prolonged. Coughing attacks are more frequent at night, coughing streaks and the end of the cough takes a deep breath, usually accompanied by vomiting. Cough can reach 1-3 months, therefore pertussis is also called "a hundred day cough"[4].

The results of the 2013 Indonesian Demographic and Health Survey (IDHS) show Infant Mortality Rate (IMR) 34 per 
1,000 Live Births and Toddler Mortality Rate (IMR) 44 per 1,000 Live Births. The target achievement in 2015 is Infant Mortality Rate (IMR) 23 per 1,000 Live Births and Toddler Mortality Rate (AKBA) 32 per 1,000 Live Births. Implementation of health development includes health efforts and its resources must be carried out in an integrated manner in order to achieve optimal results. In 2015, the Indonesian people are expected to reach a certain level of health, which is marked by their population living in an environment and healthy behavior, able to obtain adequate and fair quality health services, evenly, and have optimal health status.

Coverage of health services to baduta can illustrate the government's efforts to increase baduta access to obtain basic health services, find out as early as possible an abnormality or disease, health care and disease prevention and improve the quality of life of infants. basic immunization (BCG as many as $87,593(74.97 \%)$, DPT /, HB1-3 as much as $75.320(65 \%)$, Polio $1-4$ as much as $81.025(71 \%)$ and Measles as much as $79.908(69 \%)$. In 2016 Figures drop out of DPT / HB1 immunization by $2.4 \%$, this figure is lower than in 2015 which was $2.9 \%$ and in 2017 as much as $17.7 \%$ with 591 cases of diphtheria occurrence.

Based on data from the Aceh Health Service the number of DPT / HB1 and HB3 groups in 2015 was $7.5 \%$, DPT / HB1 and HB3 in 2016 were $3.0 \%$, DPT / HB1 and HB3 in 2017 were $8.2 \%$, with diphtheria cases as many as 109 cases and as many as 5 people died. Based on data from the West Aceh District Office immunization program in Buta is grouped into several types, one of which is: DPT $+\mathrm{HB} 1$, DPT3 + HB3 ,. In 2015 immunization achievements, namely DPT3 + HB3 reached 2,237 (53\%). In 2016 the DPT3 + HB3 immunization achievement reached 2,251 (55\%). In 2017 the achievement of immunization, namely DPT3 + HB3 reached 2,251 (63.9\%), and cases of diphtheria in 2018 were 10 cases where positive 2 people were negative 8 people

Based on preliminary data at the Meurebo Community Health Center in 2015, the coverage of DPT / HB3 services was 591 (92\%), out of 640 million targets, which had not reached the target of $100 \%$. In 2016, DPT / HB3 service coverage was $434(69 \%)$, out of the 632 targets of the million, which had not reached the target of $100 \%$. in 2017 the service coverage of DPT / HB 1 was $61.3 \%$, DPT / HB 2 was $52.3 \%$, DPT / HB3 was 49\%, from the total of 667 ambassador targets, which had not reached the target of $100 \%$. And there are 1 person diphtheria cases. Baduta numbered 845 million in 2018 and diphtheria cases in 2018 at the Meurebo Health Center were 1 case.

DPT can cause mild symptoms or very severe illness. This disease can attack the digestive system and nervous system. This might be due to one of them being afraid of the immunization reaction so there are some unscrupulous parents who are afraid to immunize their children. In addition, it can also be caused by other factors, such as: lack of awareness to maintain personal hygiene and the environment as well as lack of public knowledge about the dangers of disease for children and DPT / HB immunization itself which causes immunization not to be implemented .
Mother's knowledge about immunization affects the implementation of immunization, if the mother's knowledge about immunization is lacking, do not feel the need or just go along with course the provision of immunization to her clowns is not according to the schedule both in time and distance, if the mother's knowledge Regarding the provision of immunization, it is expected that the provision of immunization is usually on schedule, so that the immunization program meets the quantity and quality of infant health, ultimately impacting on improving the health status and community resources in the future.

Based on a preliminary survey of 6 mothers who have baduta, the mother's knowledge is still low where mothers who do not want to provide immunization to their clowns, for fear of the clowns fever and crying at night, then the mother ignores the benefits to be obtained from the mother for her immunization, then the actions of the mother less will DPT immunization that does not bring children when immunized which can prevent disease that will occur. Then inadequate in services including the distance so far that the implementation of the posyandu program is less than optimal, where less than optimal services are obtained by the mother because the mother is afraid of her clown being immunized. And the lack of family support where there are angry families if the clowns are immunized because of the baduta who will cry.

Based on the background above, the authors would like to examine more about " Factors Related to The Provision of DPT Immunization in Baduta in the Meureubo Puskesmas Working Area West Aceh Regency 2018"

\section{METHOD}

This research method is an analytic survey, with a cross sectional study design using primary data taken by filling out a questionnaire in the Work Area of the Meureubo Puskesmas in West Aceh Regency. This research was conducted in the Work Area of the Meureubo Puskesmas in West Aceh Regency from September 27 to October 23, 2018. The population of this study was all mothers who had a target of DPT immunization as many as 845 million in 2018 in the Work Area of the Health Center in Meurebo, West Aceh District. The sampling technique in this study is simple random sampling. Sampling using Slovin formula so that the sample size in this study were 89 respondents. The independent variable of the study was Knowledge, Attitude, Health Service Actions and Family Support, while the dependent variable was Giving DPT Immunization to Baduta.

\section{RESULTS AND DISCUSSION}

Based on the results of research conducted in the Work Area of the Meureubo Health Center in West Aceh Regency with 89 respondents involved in this study, the following results were obtained:

\section{Univariate Analysis}


4. Table 4. Attitude of Respondents

Table 1. Age of Respondent

\begin{tabular}{ccc}
\hline Age & f & \% \\
\hline $21-25$ & 15 & 16,9 \\
$26-30$ & 21 & 23,6 \\
$31-35$ & 22 & 24,7 \\
$36-40$ & 20 & 22,5 \\
$>41$ & 11 & 12,4 \\
Total & $\mathbf{8 9}$ & $\mathbf{1 0 0}$ \\
\hline
\end{tabular}

2. Table 2. Education of Respondents

\begin{tabular}{|c|c|c|}
\hline Education & $\mathbf{f}$ & $\%$ \\
\hline SD & 27 & 30,3 \\
\hline SMP & 21 & 23,6 \\
\hline SMA & 31 & 34,8 \\
\hline Perguruan Tinggi & 10 & 11,2 \\
\hline Total & 89 & 100 \\
\hline
\end{tabular}

3. Table 3. Knowledge of Respondents

\begin{tabular}{lcc}
\hline \multicolumn{1}{c}{ Knowledge } & f & \% \\
\hline Well & 39 & 43,8 \\
Not Good & 50 & 56,2 \\
\hline \multicolumn{1}{c}{ Total } & $\mathbf{8 9}$ & $\mathbf{1 0 0}$
\end{tabular}

\begin{tabular}{lcc}
\hline \multicolumn{1}{c}{ Attitude } & f & \% \\
\hline Positive & 32 & 36,0 \\
Negative & 57 & 64,0 \\
\hline \multicolumn{1}{c}{ Total } & $\mathbf{8 9}$ & $\mathbf{1 0 0}$ \\
\hline
\end{tabular}

5. Table 5. Actions of Respondents

\begin{tabular}{|c|c|c|}
\hline Actions & $\mathbf{F}$ & $\%$ \\
\hline There Is Action & 28 & 31,5 \\
\hline No Action & 61 & 68,5 \\
\hline Total & 89 & 100 \\
\hline
\end{tabular}

6. Table 6. Health Services

\begin{tabular}{lcc}
\hline \multicolumn{1}{c}{ Health Services } & f & \% \\
\hline Well & 29 & 32,6 \\
Not Good & 60 & 67,4 \\
\hline \multicolumn{1}{c}{ Total } & $\mathbf{8 9}$ & $\mathbf{1 0 0}$ \\
\hline
\end{tabular}

7. Table 7. Family Support

\begin{tabular}{lcc}
\hline \multicolumn{1}{c}{ Family Support } & f & \% \\
\hline $\begin{array}{l}\text { There is family } \\
\text { support }\end{array}$ & 31 & 34,8 \\
No family support & 58 & 65,2 \\
\hline \multicolumn{1}{c}{ Total } & $\mathbf{8 9}$ & $\mathbf{1 0 0}$ \\
\hline
\end{tabular}

8. Table 8. Giving DPT Immunization to Baduta

\begin{tabular}{lcc}
\hline $\begin{array}{c}\text { Giving DPT } \\
\text { Immunization }\end{array}$ & F & \% \\
\hline There is & 41 & 46,1 \\
There is no & 48 & 53,9 \\
\hline \multicolumn{1}{c}{ Total } & $\mathbf{9 8}$ & $\mathbf{1 0 0}$
\end{tabular}


2. Univariate Analysis

Table 9. Knowledge factor related to DPT immunization in Baduta in the working area of the Meureubo Puskesmas, West Aceh Regency 2018

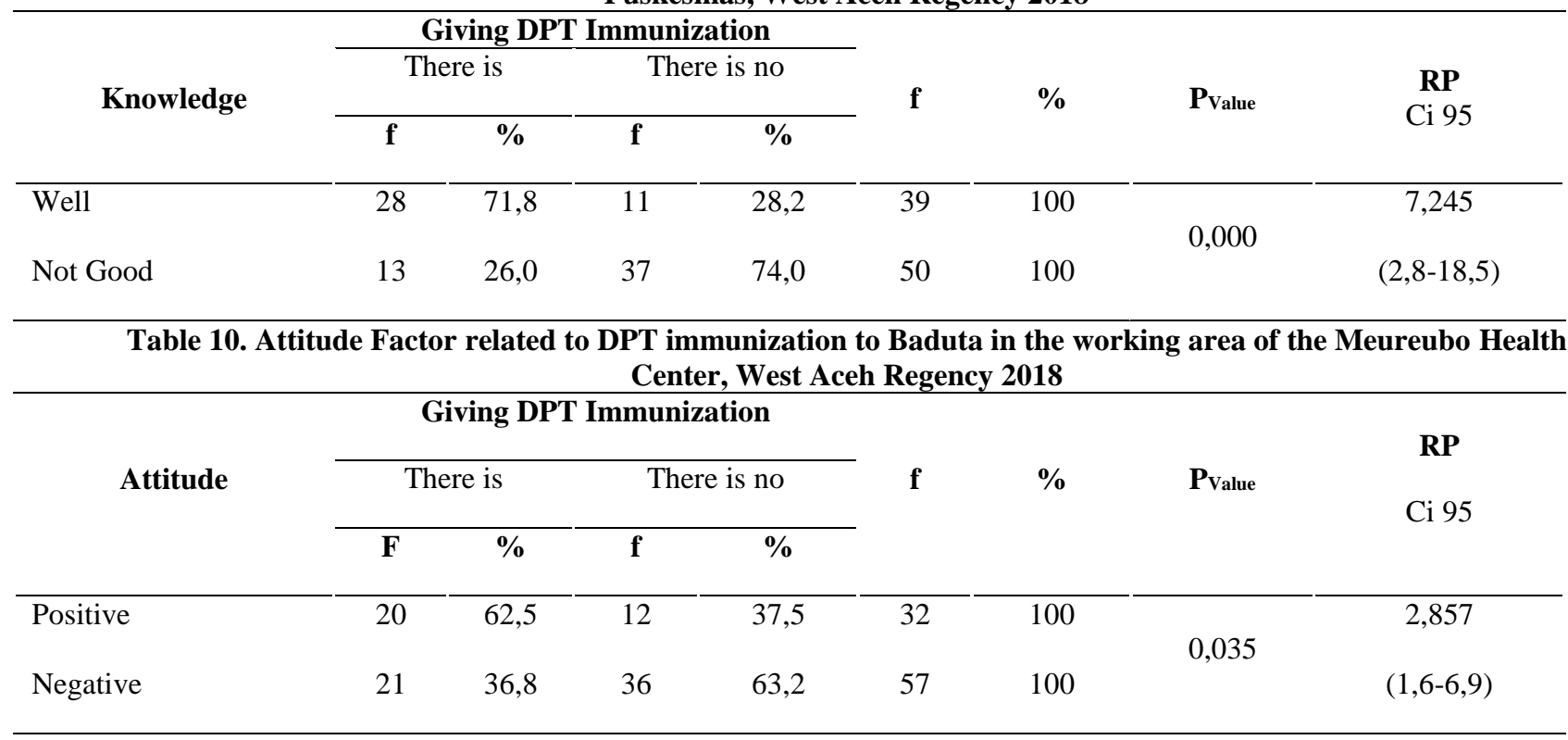

Table 11. Action Factor related to DPT immunization in Baduta in the working area of the Meureubo Health Center, West Aceh Regency 2018

\begin{tabular}{|c|c|c|c|c|c|c|c|c|}
\hline \multirow{3}{*}{ Actions } & \multicolumn{4}{|c|}{ Giving DPT Immunization } & \multirow{3}{*}{$\mathbf{f}$} & \multirow{3}{*}{$\%$} & \multirow{3}{*}{$\mathbf{P}_{\text {Value }}$} & \multirow{3}{*}{$\begin{array}{c}\mathbf{R P} \\
\text { Ci } 95\end{array}$} \\
\hline & \multicolumn{2}{|c|}{ There is } & \multicolumn{2}{|c|}{ There is no } & & & & \\
\hline & $\mathbf{f}$ & $\%$ & $\mathbf{f}$ & $\%$ & & & & \\
\hline There Is Action & 18 & 64,3 & 10 & 35,7 & 28 & 100 & & 2,974 \\
\hline No Action & 23 & 37,7 & 38 & 62,3 & 61 & 100 & 0,035 & $(1,1-7,5)$ \\
\hline
\end{tabular}

Table 12. Health Service Factor related to DPT immunization in Baduta in the work area of Meureubo Health Center, West Aceh Regency 2018

\begin{tabular}{|c|c|c|c|c|c|c|c|c|}
\hline \multirow{3}{*}{ Health Services } & \multicolumn{4}{|c|}{ Giving DPT Immunization } & \multirow{3}{*}{ f } & \multirow{3}{*}{$\%$} & \multirow{3}{*}{$\mathbf{P}_{\text {Value }}$} & \multirow{3}{*}{$\begin{array}{c}\mathbf{R P} \\
\text { Ci } 95\end{array}$} \\
\hline & \multicolumn{2}{|c|}{ There is } & \multicolumn{2}{|c|}{ There is no } & & & & \\
\hline & $\mathbf{f}$ & $\%$ & $\mathbf{f}$ & $\%$ & & & & \\
\hline Well & 19 & 65,5 & 10 & 34,5 & 29 & 100 & & 3,282 \\
\hline Not Good & 22 & 36,7 & 38 & 63,3 & 60 & 100 & & $(1,2-8,3)$ \\
\hline
\end{tabular}

Table 13. Family Support Factor related to DPT immunization in Baduta in the work area of Meureubo Health Center, West Aceh Regency 2018

\begin{tabular}{|c|c|c|c|c|c|c|}
\hline \multirow{3}{*}{ Family Support } & \multicolumn{2}{|c|}{ Giving DPT Immunization } & \multirow{3}{*}{$\mathbf{f}$} & \multirow{3}{*}{$\%$} & \multirow{3}{*}{$\mathbf{P}_{\text {Value }}$} & \multirow{3}{*}{$\begin{array}{c}\mathbf{R P} \\
\text { Ci } 95\end{array}$} \\
\hline & There is & There is no & & & & \\
\hline & $\mathrm{F} \quad \%$ & f $\%$ & & & & \\
\hline
\end{tabular}




\begin{tabular}{lcccccccc}
\hline $\begin{array}{l}\text { There is family } \\
\text { support }\end{array}$ & 20 & 64,5 & 11 & 35,5 & 31 & 100 & & 1,290 \\
No family support & 21 & 36,2 & 37 & 63,8 & 58 & 100 & 0,020 & $(1,2-7,9)$ \\
\hline
\end{tabular}

\subsection{Relationship of Knowledge with Giving DPT Immunization to Baduta}

Based on the chi square statistical test results obtained value of Pvalue $=0,000$ and this is smaller than $\alpha=0.05$ (Pvalue $=0,000<\alpha=0.05$ ) so that there is described a significant relationship between knowledge factors with DPT immunization in the work area Meureubo Health Center, West Aceh Regency. Based on the results of the 7.245 Prevalence Ratio, it can be concluded that respondents with poor knowledge will have 7,245 times the opportunity who do not provide DPT immunization to baduta compared to respondents who have good knowledge.

The results of the above study are in line with the research of Emilya, et al (2017), in Kelurahan Lambung Bukit Kota Padang where there is a relationship of knowledge with the provision of Complete Basic Immunization with a Pvalue $=$ 0.001 .

According to Daryanto (2010) Knowledge is information that is found and obtained by humans through observing reason to recognize an object or event that has never been seen or felt before. Knowledge is often used as an indifference to find out someone's intelligence level. Bloom in his book Notoatmodjo (2010: 50) explains that knowledge is the result of human sensing, or the result of knowing someone about objects through their senses (eyes, nose, ears, etc.) A mother who has good knowledge, but there is no encouragement and motivation from within the mother herself and her family to bring the child immunized will negatively affect the behavior of the mother in giving immunizations to toddlers. Likewise vice versa mothers whose knowledge is lacking, behavior will be positive if there is encouragement from the family and explanations from health workers about the importance of immunization in infants [5].

Based on the findings of the researchers in the field, the respondent had good knowledge and gave DPT immunization because he knew that diphtheria is a disease caused by Corynebacterium diphtheria and its transmission could be due to direct contact with sufferers through sneezing or coughing or indirect contact. On the other hand, the respondents' knowledge is not good and they do not give DPT immunization because they are afraid that Baduta experiences some symptoms such as fever about $38^{\circ} \mathrm{C}$, nausea, vomiting, pain, do not know the cause of diphtheria such as coughing more often at night, coughing streaks and the end of the cough takes a deep breath, usually accompanied by vomiting.

\subsection{Relationship between Attitude and Giving DPT Immunization to Baduta}

Based on the chi square statistical test results obtained value of Pvalue $=0.035$ and this is smaller than $\alpha=0.05$ (Pvalue $=0.035<\alpha=0.05)$ so that there is described a significant relationship between attitude factors with DPT immunization in the work area Meureubo Health Center, West Aceh Regency. Based on the results of the 2.857 Prevalence Ratio, it can be concluded that respondents who are negative will have an opportunity of 2,857 times who do not provide DPT immunization to baduta compared to respondents who are positive.

The above research results are in line with the research of Tampemawa, et al, Ranotana Weru Community Health Center in Manado where there is a relationship between attitude and immunization status with a Pvalue $=0.003$ [6]. An individual is very closely related to their respective attitudes as personal characteristics. Attitude in general is often interpreted as an action taken by an individual to provide a response to a matter. Understanding the attitude explained by Saifudin Azwar attitude is interpreted as a reaction or response that arises from an individual against an object which then raises individual behavior towards the object in certain ways [7].

Attitudes, beliefs and behaviors of maternal health are also important, because the use of health facilities by children is closely related to the attitudes, behaviors, and beliefs of mothers about health so that it can affect immunization status. The problem of understanding and participation of parents in the immunization program will not be a major obstacle if adequate education about it is provided [8].

Based on the findings of the researchers in the field, the respondent was positive and gave DPT immunization because the respondents were ignorant about bringing toddlers for DPT immunization and always anticipated the prevention of crying children at night. On the other hand, the respondent was negative and did not give DPT immunization because the respondent ignored the toddler when he coughed, as if he did not know how to handle and did not know when to face a fever and babbling baby and did not bother to bring a toddler for DPT immunization.

\subsection{Relationship between Actions and DPT Immunization for Baduta}

Based on the chi square statistical test results obtained value of Pvalue $=0.035$ and this is smaller than $\alpha=0.05$ (Pvalue $=0.035<\alpha=0.05$ ) so that there is described a significant relationship between action factors with DPT immunization in the work area Meureubo Health Center, West Aceh Regency. Based on the results of the 2.974 Prevalence Ratio, it can be concluded that respondents who did not have an action would have as much as 2.974 times as likely to not have DPT immunization compared to respondents who did.

The results of the above study are in line with research conducted by Hudhah and Hidajah at the Gayam Health Center in Sumenep Regency, where there is a correlation between the actions of DPT immunization and the Pvalue = 0,000 [9]. 
Action is an impulse from within a person that causes that person to carry out activities in order to achieve a goal [10]. Mother's actions affect the mother's refusal to provide complete basic immunizations. In addition, the mother's attitude is also related to the refusal of giving complete basic immunization where one's emotional life or evaluation of the object, and the tendency to act [11].

Based on the findings of the researchers in the field that the respondent has actions and provides DPT immunization because the respondent always records the immunization schedule of the baduta and brings children DPT immunization as much as $3 \mathrm{x}$. On the other hand, the respondent did not have any action and did not provide DPT immunization to the baduta because the maternal respondent did not immunize the child on time because he recorded the baduta immunization schedule.

\subsection{Relationship between Health Services and DPT Immunization for Baduta}

Based on the chi square statistical test results obtained value of Pvalue $=0.020$ and this is smaller than $\alpha=0.05$ (Pvalue $=0.020<\alpha=0.05)$ so that there is described a significant relationship between health service factors with DPT immunization in the region the work of the Meureubo Health Center, West Aceh Regency. Based on the results of the 3.282 Prevalence Ratio, it can be concluded that respondents who get poor health services will have as much as 3,282 times more likely to give DPT immunization than those who get good health services.

The results of the above study are in line with the research of Tiani, et al in the city of Banda Aceh where there is a relationship between health services and immunization with a Pvalue $=0.004$ [12]

Public health services are organized by groups and communities that aim to maintain and improve health which refers to promotive and preventive actions. These community service efforts are implemented in certain community health centers such as puskesmas[13]. Health workers make an effort and are responsible, providing health services to individuals and the professional community will affect the health status of the community. So it is expected that mothers want to immunize their babies by giving or explaining the importance of immunization [14].

Based on the findings of the researchers in the field, respondents who get good health services and provide DPT immunization to the undergraduate because health respondents provided that you get easily accessible and DPT immunization services are always used on time. On the other hand, respondents who received poor health services and did not provide DPT immunization because they were found to be less friendly by officers and the services received made children sick where fever at night and fuss.

\subsection{Relationship between Family Support and DPT Immunization for Baduta}

Based on the chi square statistical test results obtained value of Pvalue $=0.020$ and this is smaller than $\alpha=0.05$ (Pvalue $=0.020<\alpha=0.05$ ) so that there is described a significant relationship between family support factors with DPT immunization in the region the work of the Meureubo Health Center, West Aceh Regency. Based on the results of the Prevalence Ratio of 1.290 , it can be concluded that respondents who do not have family support will have as much as 1,290 times the chance to give DPT immunizations to the pooruta compared to respondents who have family support.

The above research results are in line with the research of Azzahra and Susanti in Aceh Besar where family support with immunizations with a value of Pvalue $=0.001$ [15] Family support is a form of interpersonal relationships that protect a person from the effects of bad stress [16]. Family support according to Fridman is an attitude, an act of family acceptance towards family members, in the form of informational support, assessment support, instrumental support and emotional support [17]. So family support is a form of interpersonal relationships that includes attitudes, actions and acceptance of family members, so that family members feel someone is paying attention. So family social support refers to social supports that are seen by family members as something that can be accessed or held for families who are always ready to provide help and assistance if needed.

Cultural environment where people learn a lot from the surrounding cultural environment. The influence of the family on the formation of attitudes is very large because the family is the closest person to the other family members. If the family's attitude towards immunization is not very responsive and ignores or even the implementation of immunization activities, the implementation of immunization will not be carried out by the baby's mother because there is no support from the family [14].

Based on the findings of the researchers in the field, the respondents who have family support and provide DPT immunization to the baduta because the respondent always supports you to bring the baduta immunized and delivered. On the other hand, respondents who did not have family support and did not provide DPT immunization to the baduta because the respondents lacked the support to bring the baduta immunized because the family thought that immunization would only make the baduta sick.

\section{CONCLUSION}

1. There is a relationship between knowledge factors with DPT immunization in Baduta in the Work Area of Meureubo Health Center, West Aceh Regency (Pvalue $=0,000<\alpha=0.05, \mathrm{RP}=7.245$ ).

2. There is a relationship between attitude factors with DPT immunization in Baduta in the Work Area of the Meureubo Health Center in West Aceh Regency (Pvalue $=0.035<\alpha=0.05, \mathrm{RP}=2.857$ ).

3. There is a relationship between action factors with DPT immunization in Baduta in the Work Area of the Meureubo Public Health Center in West Aceh District $($ Pvalue $=0.035<\alpha=0.05, \mathrm{RP}=2.974$ ).

4. There is a relationship between health services with DPT immunization in Baduta in the Work Area of Meureubo Health Center, West Aceh Regency $($ Pvalue $=0.020<\alpha=0.05, R P=3.282$ ). 
5. There is a relationship between family support and DPT immunization in Baduta in the Work Area of Meureubo Health Center, West Aceh Regency $($ Pvalue $=0.020<\alpha=0.05, \mathrm{RP}=1.290)$.

\section{REFERENCES}

[1] Ministry of Health Republic of Indonesia. 2012. Kesehatan Dalam Kerangka Sustainable Development Goals (SDGs). Dirjen Bina Gizi KIA

[2] Ranuh, et all.2010. Buku Imunisasi di Indonesia. Jakarta: Satgas Imunisasi IDAI.

[3] Mahayu, P. 2014. Imunisasi dan Nutrisi. Jogjakarta: Buku Biru.

[4] Tampera 2016 Tampemawa, et al. 2015. Hubungan antara Pengetahuan, Sikap dan Motivasi Ibu Tentang Imunisasi dengan Status Imunisasi Anak Usia 12-24 Bulan di Pusat Kesehatan Masyarakat Ranotana Weru Kota Manado. Jurnal Kesehatan Masyarakat. Nomor 1 Volume 4. ISSN 45632

[5] Azwar, S. 2010. Sikap Manusia Teori Dan Penerapannya. Yogyakarta: Pustaka Pelajar

[6] Ali, M. 2010. Pengetahuan, Sikap dan Perilaku Ibu Bekerja dan Ibu Tidak Bekerja Tentang Imunisasi. Jakarta [7] Hudhah dan Hidajah. 2017. Perilaku Ibu Dalam Imunisasi Dasar Lengkap Di Puskesmas Gayam Kabupaten Sumenep. Jurnal Promkes Vol. 5 No. 2

[8] Suparyanto. 2011. Konsep Kelengkapan Imunisasi. Jakarta: Salemba Medika.

[9] Notoadmojo. 2010. Pendidikan dan Perilaku Kesehatan. Jakarta. Rineka Cipta. Ranuh, I.G.N, dkk.

[10] Tiani, et al. 2016. Peran Petugas Imunisasi dalam Pemberian Vaksinasi Pentavalen. Jurnal Ilmu Keperawatan (2016) 4:1 ISSN: 2338-6371

[11] Kemenkes RI. 2010. Informasi Dasar Imunisasi Rutin Serta Kesehatan Ibu Dan Anak bagi Kader, Petugas Lapangan Dan Organisasi Kemasyarakatan. Jakarta: Kemenkes RI.

[12] Azzahra dan Susanti. 2014. Dukungan Keluarga Terhadap Ibu Dalam Melaksanakan Imunisasi. Jurnal Kesehatan Masyarakat. Nomor 2.Volume 3. ISSN 87653 [13] Kaplan, H.L, Sadock, B.J dan Grebb, J.A. 2012. Sinopsis Psikiatri, Ilmu Pengetahuan Perilaku Psikiatri Klinis. Edisi 7. Jilid II. Jakarta: Binaputra Aksara.

[14] Friedman, M. 2010. Buku Ajar Keperawatan keluarga: Riset, Teori, dan Praktek. Edisi ke-5. Jakarta: EGC.

[15] Rikesdas. 2013. Laporan Nasional Riskesdas Tahun 2013. Jakarta: Kemenkes RI Satgas Imunisasi IDAI, 2010. Buku Imunisasi di Indonesia. Jakarta

[16] Sugiyono. 2010. Metode Penelitian Pendidikan, Pendekatan Kuantitatif, Kualitatif dan R\&D. Bandung: Penerbit Alfabeta.

[17] Sugiyono, 2012. Metode Penelitian Kuantitatif, Kualitatif Dan R \& Bandung: Alfabeta.

[18] Suparyanto. 2011. Konsep Kelengkapan Imunisasi. Jakarta: Salemba Medika.

[19] Tampemawa, et al. 2015. Hubungan antara Pengetahuan, Sikap dan Motivasi Ibu Tentang Imunisasi dengan Status Imunisasi Anak Usia 12-24 Bulan di Pusat Kesehatan Masyarakat Ranotana Weru Kota Manado. Jurnal Kesehatan Masyarakat. Nomor 1 Volume 4. ISSN 45632

[20] Tiani, et al. 2016. Peran Petugas Imunisasi dalam Pemberian Vaksinasi Pentavalen. Jurnal Ilmu Keperawatan (2016) 4:1 ISSN: 2338-6371

[21] Triana. 2016. Faktor Yang Berhubungan Dengan Pemberian Imunisasi Dasar Lengkap Pada Bayi Tahun 2015. Jurnal Kesehatan Masyarakat Andalas Volume 10, Nomor 2. 